\title{
Decreased The Risk Of Hyperbilirubinemia Incidence With The Initiation Of Early Breastfeeding
}

\author{
Arief Yanto', Rochayati², Edy Wuryanto $^{3}$ \\ 1,3 Fakultas Ilmu Keperawatan dan Kesehatan, Universitas Muhammadiyah Semarang \\ 2 Rumah Sakit Islam Muhammadiyah Kendal
}

\begin{tabular}{|c|c|}
\hline Article Info & Abstract \\
\hline $\begin{array}{l}\text { Article History: } \\
\text { Accepted April 13rd } 2018 \\
\text { Key words: } \\
\text { Hiperbilirubinemia } \\
\text { Early Initiation } \\
\text { breastfeeding } \\
\text { Neonatus }\end{array}$ & $\begin{array}{l}\text { Hyperbilirubinemia is a state where increase value of in serum bilirubin in } \\
\text { the blood more }>5 \mathrm{mg} / \mathrm{dl} \text {, which is clinically characterized by jaundice on } \\
\text { sclera and skin, hyperbilirubinemia can be caused by physiological } \\
\text { processes, non-physiological, or a combination of both. Neonates were } \\
\text { given early initiation will result in the expenditure of meconium early so } \\
\text { tend to have a low risk of the occurrence of physiological } \\
\text { hyperbilirubinemia. Research will aim to detect early initiation on the } \\
\text { incidence of neonates physiologic hyperbilirubinemia in neonates born at } \\
\text { Khadijah room Islamic Hospital Muhammadiyah Kendal. Research kind } \\
\text { quasi-experiment by using plant form post test only in a body (one group } \\
\text { post test only design). Population in this research patient newborn at } \\
\text { Khadijah room Islamic Hospital Muhammadiyah Kendal. Research sample } \\
\text { as much as } 30 \text { respondens early initiation and } 30 \text { respondens not early } \\
\text { initiation by using technique purposive sampling. Data analysis included } \\
\text { univariate analysis by finding frequency distribution, bivariate analysis } \\
\text { with Mann-Whitney Test. The research result of bivariate analysis shows } \\
\text { that neonates with early initiation total serum bilirubin value performed } \\
\text { intervention group averaged } 8,200 \text { mg/dl while control group averaged } \\
11,647 m g \text { /dl. The initiation of early breastfeeding (IMD) effect on total } \\
\text { serum billirubin content of the neonatus. The variables that have } \\
\text { contributed to the total serum billirubin content were the implementation } \\
\text { of early breastfeeding initiation (IMD) with an effect of } 61.2 \% \text { and } \\
\text { influenced by other variables of } 38.8 \% \text {. The conclusion there is influence of } \\
\text { early initiation of suckling on physiological hyprbilirubinemia at Islamic } \\
\text { Hospital Muhammadiyah Kendal. }\end{array}$ \\
\hline
\end{tabular}

\section{PENDAHULUAN}

Hiperbilirubinemia merupakan kondisi yang menunjukkan kadar bilirubin serum total $>5 \mathrm{mg} / \mathrm{dl}$ (Kosim, 2008). Tingginya kadar billirubin dimanifestasikan dengan kulit kekuningan ikterus atau jaundice.
Ikterus pada bayi baru lahir merupakan gejala fisiologis maupun patologis. Ikterus fisiologis terdapat pada 25-50\% bayi baru lahir cukup bulan dan lebih tinggi lagi pada BBL kurang bulan, muncul pada hari kedua atau ketiga setelah persalinan, tidak terdapat penyakit penyerta, kadarnya tidak

Corresponding author:

Arief Yanto

arief.yanto@unimus.ac.id

Media Keperawatan Indonesia, Vol 1 No 2, Juni 2018

e-ISSN: 2615-1669

DOI:10.26714/mki.1.2.2018.25-31 
membahayakan dan tidak menyebabkan kematian pada bayi. Ikterus patologis memiliki dasar penyakit atau kelainan secara patologis atau kadar bilirubinnya mencapai suatu nilai yang tinggi disebut hiperbilirubunemia. Dasar patologis yang dimaksud yaitu jenis bilirubin, saat timbul dan hilangnya ikterus, serta penyebabnya (Pudjiadi, 2011).

Kejadian hiperbilirubinemia di Amerika sebayak $65 \%$ dari jumlah total kelahiran dan di Malaysia $75 \%$ dari jumlah total kelahiran. Kejadian hiperbilirubinemia pada bayi cukup bulan di beberapa rumah sakit pendidikan di Indonesia antara lain RSCM, RS Dr Sardjito, RS Dr Soetomo dan RS Dr Kariadi bervariasi dari $13,7 \%$ sampai dengan 85\% (Irianti, A., 2015). Data dari RS Dr Kariadi tahun 2003 mendapatkan insiden ikterus neonatorum $12 \%$ pada bayi baru lahir, 78\% merupakan ikterus fisiologis. Kasus kematian bayi terkait dengan hiperbilirubinemia terhadap seluruh bayi yang dirawat pada tahun 2003 di RS Dr Sardjito Yogyakarta 24\% dan di RS Dr Kariadi Semarang 13,1\% (Sareharto, 2016).

Hiperbilirubinemia sebagian besar adalah fisiologis dan tidak membutuhkan terapi khusus namun ada beberapa kasus yang dapat berhubungan dengan beberapa penyakit hemolitik, kelainan metabolik, dan endokrin, kelainan hati serta infeksi. Pada kadar $>20 \mathrm{mg} /$ dl bilirubin indirek dapat menembus sawar darah otak dan bersifat toksik terhadap sel otak. Penanganan primer hiperbilirubinemia yang di rekomendasikan adalah inisiasi menyusu dini atau pemberian air susu ibu segera setelah lahir (Pohlman, M.N., Nursanti, I., \& Anto, Y.V., 2015).

Pemberian ASI secara dini dan ekslusif akan meningkatkan kekebalan pada bayi baru lahir sehingga berdampak pada penurunan angka kematian bayi (AKB) dan balita sejalan dengan usaha pemerintah melalui Millenium Development Goals (MDG'S). ASI berperan penting bagi tumbuh kembang dan daya tahan tubuh bagi bayi. Oleh karena pemberian ASI sedini mungkin harus diberikan dari ibu yang baru melahirkan. Produksi air susu ibu pada hari pertama kelahiran mengandung kolostrum yang dapat meningkatkan kekebalan dan melindungi bayi dari berbagai penyakit infeksi. Kolustrum bermanfaat untuk kekebalan tubuh bayi juga bermanfaat untuk mempercepat pengeluaran tinja pertama bayi (mekonium). Penelitian yang dilakukan oleh Saputra di kamar rawat kebidanan di rumah sakit Ahmad Muhtar Bukittinggi tahun 2012 menggambarkan bahwa pemberian IMD pada bayi baru lahir sangat efektif untuk menurunkan derajat hiperbilirubinemia fisiologis dibandingkan dengan yang tidak dilakukan IMD dengan nilai 1 banding 2 (Saputra, N.P.K., \& Lasmini, P.S., 2016).

Menurut laporan trimester terakhir (bulan Juli, Agustus, September 2017) poliklinik Rumah Sakit Islam Muhammadiyah Kendal angka kunjungan bayi mencapai 408 kunjungan. Dari 408 kunjungan yang ada, kejadian hiperbilirubinemia cukup banyak yaitu 217 bayi mengalami ikterus. Selama ini belum pernah ada yang melakukan penelitian yang berkaitan dengan hiperbilirubinemia fisiologis bayi di poliklinik Rumah Sakit Islam Muhammadiyah kendal.

\section{METODE}

Penelitian ini merupakan penelitian Kuantitatif eksperimen semu (quasi experiment) dengan pendekatan post test only design. Responden penelitian terdiri dari dua kelompok yaitu kelompok intervensi atau bayi yang dilakukan inisiasi menyusu dini (IMD) dan kelompok kontrol atau tidak dilakukan inisiasi menyusu dini. Responden merupakan ibu post partum dan bayi baru lahir yang dilahirkan di ruang Khadijah Rumah Sakit Islam Muhammadiyah Kendal sejumlah 60 orang yang didapatkan melalui purposive sampling. 
Penelitian dilakukan di ruang Khadijah rumah sakit Islam Muhammadiyah Kendal. Instrumen penelitian yang digunakan antara lain: instruksi kerja inisiasi menyusu dini, lembar observasi, lembar hasil laboratorium kadar bilirubin serum, dan formulir-formulir lain yang berkaitan dengan pencatatan data.

Proses penelitian berlangsung dari tanggal 1 November 2017 sampai dengan 30 Januari 2018. Pengaruh inisiasi menyusu dini terhadap penurunan resiko terjadinya hiperbillirubinemia diketahui dengan melakukan uji beda rerata nilai billirubin serum total bayi antara kelompok intervensi dengan kelompok kontrol. Analisis yang digunakan adalah uji non parametrik Mann-Whitney test karena sebaran data nilai billirubin serum total berdistribusi tidak normal.

\section{HASIL}

Kategori jenis kelamin bayi ibu post partum responden penelitian pada kelompok yang dilakukan inisiasi menyusu dini (IMD) memiliki proporsi yang hampir sama antara laki-laki dan perempuan. Begitu juga dengan kelompok yang tidak dilakukan inisiasi menyusu dini (IMD) memiliki proporsi jenis kelamin bayi yang hampir sama.

Berat badan bayi pada kedua kelompok memiliki berat badan bayi yang hampir sama. Berat badan bayi kelompok yang dilakukan inisiasi menyusu dini (IMD) memiliki nilai terendah 2400 gr dan nilai tertinggi 2800 gr. Sebaran data berdistribusi normal ( $p$-value $=0,737$ ). Sedangkan kelompok yang tidak dilakukan inisiasi menyusu dini (IMD) memiliki nilai terendah 2200 gr dan nilai tertinggi 2900 gr. Sebaran data berdistribusi normal ( $p$ value $=0,393$ ).

Kedua kelompok memiliki usia gestasi yang hampir sama. Usia gestasi kelompok yang dilakukan inisiasi menyusu dini (IMD) memiliki nilai terendah 37 minggu dan nilai tertinggi 41 minggu. Sebaran data berdistribusi tidak normal ( $p$-value $=0,004$ ). Sedangkan kelompok yang tidak dilakukan inisiasi menyusu dini (IMD) memiliki nilai terendah 35 minggu dan nilai tertinggi 42 minggu. Sebaran data berdistribusi normal (p-value $=0,068)$.

Hasil uji beda proporsi dan uji beda rerata menunjukkan bahwa jenis kelamin bayi, berat badan bayi dan usia gestasi pada kedua kelompok tidak memiliki perbedaan yang signifikan. Sehingga dapat disimpulkan bahwa kedua kelompok memiliki baseline yang sama atau homogen.

\section{Tabel 1}

Karakteristik responden penelitian berdasarkan jenis kelamin bayi, berat badan bayi dan usia gestasi, $n=60$ responden

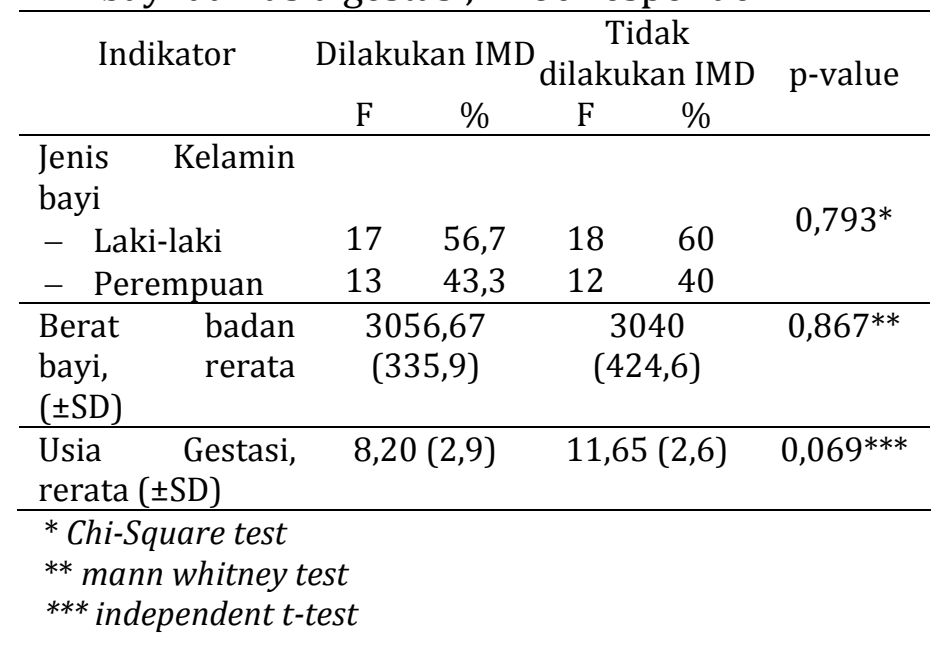

Kadar billirubin serum total pada kelompok yang dilakukan inisiasi menyusu dini (IMD) memiliki rata-rata yang lebih rendah daripada kadar billirubin serum total kelompok yang tidak dilakukan inisiasi menyusu dini (IMD). Kadar billirubin serum total kelompok yang dilakukan inisiasi menyusu dini (IMD) memiliki rata-rata $8,2 \pm 2,9$ dengan nilai terendah 0,9 dan nilai tertinggi 11. Sebaran data berdistribusi tidak normal ( $\mathrm{p}$-value=0,008). Sedangkan kadar billirubin serum total kelompok yang tidak dilakukan inisiasi menyusu dini (IMD) memiliki rata-rata $11,65 \pm 2,6$ dengan nilai terendah 6,5 dan nilai tertinggi 15,9. Sebaran data berdistribusi normal (pvalue $=0,472$ ). 


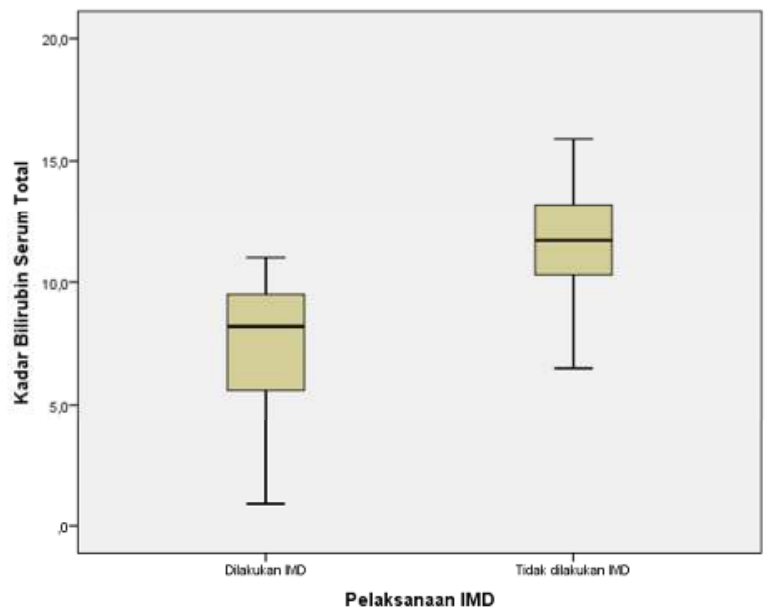

Gambar 1

Perbedaan rerata kadar billirubin serum total berdasarkan pelaksanaan inisiasi menyusu dini (IMD)

Pengaruh pelaksanaan inisiasi menyusu dini (IMD) dapat diketahui dengan melakukan uji beda rerata kadar billirubin serum total antara kedua kelompok. Analisis peperbedaan dilakukan dengan melakukan uji non parametrik MannWhitney test karena data berdistribusi tidak normal.

Hasil penelitian menunjukkan bahwa terdapat perbedaan yang bermakna antara kadar billirubin serum total kelompok yang dilakukan inisiasi menyusu dini (IMD) dengan yang tidak dilakukan inisiasi menyusu dini (IMD) ( $p$-value $=0,000)$. Sehingga dapat disimpulkan bahwa pelaksanaan inisiasi menyusu dini (IMD) berpengaruh terhadap jumlah kadar billirubin serum total bayi.

Analisis lanjutan dilakukan untuk mengetahui variabel yang berkontribusi dan besar kontribusi atau pengaruh yang diberikan oleh variabel pelaksanaan inisiasi menyusu dini (IMD) terhadap kadar billirubin serum total. Analisis yang digunakan adalah regresi linier berganda.

Hasil uji regresi menunjukkan nilai R square pada model terakhir menunjukkan bahwa variabel yang berperan terhadap kadar billirubin serum total adalah pelaksanaan inisiasi menyusu dini (IMD) dengan pengaruh sebesar $61,2 \%$ dan dipengaruhi oleh variabel lain sebesar 38,8\%.

Hasil uji parsial / Individu menunjukkan pvalue variabel pelaksanaan inisiasi menyusu dini (IMD) <0,05 yang berarti bahwa variabel tersebut mempengaruhi kadar billirubin serum total bayi.

Tabel 2

Analisis variabel yang berpengaruh terhadap kadar billirubin serum total, $\mathrm{N}=60$ responden

\begin{tabular}{lcc}
\hline \multicolumn{1}{c}{ Variabel } & $\begin{array}{c}\text { Nilai koefisien } \\
\text { regresi }\end{array}$ & p-value \\
\hline Konstanta & 3,293 & 0,005 \\
Pelaksanaan IMD & 4,177 & 0,000 \\
\hline Variabel Dependen: kadar billirubin serum \\
total
\end{tabular}

Persamaan regresi linier berganda didapatkan:

$Y=3,293+4,177 X$

Berdasarkan persamaan regresi linier berganda di atas dapat dijelaskan sebagai berikut:

1. Konstanta sebesar 3,293 menyatakan bahwa jika tidak ada pengaruh inisiasi menyusu dini (IMD) maka skor kadar billirubin serum total sebesar 3,293

2. Koefisien regresi $X$ sebesar 4,177 menyatakan bahwa setiap peningkatan skor inisiasi menyusu dini (IMD) sebesar satu poin, maka skor kadar billirubin serum total akan meningkat (lebih buruk) 417,7\%. Atau dengan kata lain bahwa setiap dilakukan inisiasi menyusu dini (IMD) dapat menurunkan kadar billirubin serum total sebesar $417,7 \%$.

\section{PEMBAHASAN}

Billirubin merupakan pigmen berwarna kuning yang berasal dari perombakan heme dari hemoglobin yang terjadi dalam proses pemecahan eritrosit dan sekitar 20\% bilirubin di dalam tubuh berasal dari perombakan zat-zat lain. Tingginya kadar billirubin atau hiperbilirubinemia dapat 
terjadi karena adanya peningkatan produksi atau penurunan bersihan bilirubin dan lebih sering terjadi pada bayi yang belum matur. Hiperbilirubinemia dapat terjadi karena proses fisiologis maupun patologis, dan beberapa kasus hiperbillirubinemia disebabkan kombinasi keduanya.

Faktor yang dapat meningkatkan resiko hiperbilirubinemia pada bayi antara lain pemberian ASI, usia gestasi (kehamilan), jenis persalinan, paritas ibu dan berat badan bayi. Penelitian ini bertujuan mengetahui pengaruh pelaksanaan inisiasi menyusu dini (IMD) terhadap kejadian hiperbillirubinemia. Dalam upaya membuktikan hipotesis tersebut maka variabel lain yang mempengaruhi kejadian hiperbillirubinemia dilakukan pengukuran dan dikontrol.

Jenis persalinan dikontrol dengan menerapkan kriteria inklusi dan eksklusi pemilihan responden penelitian. Semua responden penelitian ini merupakan ibu post partum dengan satu jenis persalinan.

Kematangan usia kehamilan dapat berpengaruh terhadap kematangan semua organ bayi. Usia gestasi yang tidak cukup minggu akan berpengaruh pada tingginya kadar billirubin serum. Peningkatan kadar bilirubin serum ini tergolong kategori yang ringan dan dapat menurun tanpa pengobatan (Mathindas, 2013). Peningkatan kadar bilirubin serum ini disebabkan oleh syndrome atau akumulasi dari berbagai faktor yang berhubungan dengan kematangan fisiologis bayi baru lahir. Hasil penelitian menunjukkan bahwa usia kehamilan ibu pada kedua kelompok adalah setara (homogen). Sehingga dapat disimpulkan bahwa kedua kelompok perlakuan memiliki baseline yang sama berdasarkan usia kehamilan ibu.

Paritas tidak berhubungan secara langsung dengan kejadian hiperbillirubinemia. Akan tetapi paritas merupakan salah satu faktor yang berhubungan dengan pelaksanaan menyusu dini bayi. Kemampuan laktasi ibu dipengaruhi oleh pengalaman laktasi sebelumnya. Sehingga ibu multipara cenderung lebih berhasil dalam laktasi daripada ibu primipara. Hasil penelitian menunjukkan bahwa kedua kelompok perlakuan memiliki paritas yang sama.

Bayi yang lahir sebelum matur (matang) atau lahir dengan berat badan yang sangat rendah masih terlalu lemah untuk menghisap ASI dari ibunya. Berat badan yang kurang dari 1200 gram cenderung untuk menyusu sangat kurang, sehingga ASI harus dikeluarkan dan diberikan kepada bayi secara manual. Refleks rooting berfungsi dengan baik pada usia gestasi 32 minggu, koordinasi refleks untuk menghisap, menelan dan bernapas biasanya terbentuk pada gestasi minggu ke-32.

Hasil penelitian menunjukkan bahwa kedua kelompok memiliki baseline yang sama berdasarkan berat badan bayi. Perbedaan yang tidak signifikan tersebut menjelaskan bahwa kadar billirubin yang diukur dalam penelitian tersebut tidak dipengaruhi oleh perbedaan berat badan bayi.

Bayi baru lahir harus segera diberikan ASI dari ibunya, terutama pada bayi berat badan lahir rendah (prematur) jika tidak terdapat komplikasi seperti asfiksia, sepsis infeksi dan malformasi. Bayi yang lahir dengan berat badan lahir rendah atau prematur dapat tetap diberikan ASI segera setelah lahir.

Hasil penelitian ini menunjukkan bahwa inisiasi menyusu dini (IMD) dapat mengurangi resiko terjadinya hiperbillirubinemia. Hasil ini sesuai dengan studi lain yang dilakukan oleh Studi yang dilakukan oleh Saputra (2015) yang menjelaskan bahwa dengan dilakukannya IMD bayi biasanya akan cenderung berhasil dalam menyusu kemudian, dan mendapatkan kolustrum lebih awal. Pemberian kolustrum lebih awal akan mempercepat pengeluaran mekonium yang didalamnya terdapat banyak bilirubin dan 
zat sisa lainnya. Kolustrum yang didapatkan bayi pada saat IMD mengandung kadar laksansia lebih tinggi. Salah satu manfaat IMD adalah meningkatkan produksi ASI, sehingga pada kelompok yang mendapatkan IMD dilanjutkan dengan ASI eksklusif akan memiliki volume ASI lebih banyak sehingga dapat meningkatkan motilitas usus yang berakibat pengeluaran mekonium yang berwarna gelap lebih cepat.

Menurut Roesli utami (2012) dalam bukunya dengan judul "Panduan Inisiasi Menyusu Dini plus ASI Eksklusif", IMD (early initiation) atau permulaan menyusu dini adalah bayi mulai menyusu sendiri segera setelah lahir. Bayi baru lahir yang diletakkan di perut ibu dapat bergerak menuju payudara, mencari puting susu, dan kemudian menyusu sendiri. Meskipun demikian terdapat beberapa faktor yang dapat mengganggu reflek atau kemampuan bayi tersebut, seperti penggunaan obat yang diberikan saat ibu melahirkan untuk mempercepat proses persalinan yang bisa sampai ke janin melewati plasenta dan bisa menyebabkan bayi sulit menyusu. Selain obat, tindakan yang dilakukan untuk membantu proses persalinan juga mempengaruhi reflek bayi, seperti: operasi forcep, vakum, sectio caesaria, maupun episiotomi.

Hal ini dapat terjadi karena bayi-bayi yang dilakukan IMD atau yang disusui dalam satu jam pertama kelahiran dan terus disusui secara teratur akan cenderung lebih awal mengeluarkan mekonium dan mengalami kejadian sakit kuning fisiologi yang lebih rendah. Bayi yang berhasil IMD akan lebih dulu mendapatkan kolostrum dari pada yang tidak IMD. Kolostrum adalah cairan pertama yang kaya akan kekebalan tubuh terutama IgA, bagi pertumbuhan bayi, dan untuk ketahanan infeksi. Salah satu manfaat dari inisiasi menyusu dini (IMD) dan kontak skin to skin untuk bayi adalah membentuk ikatan ibu dan bayi. Inisiasi menyusu dini membuat kadar bilirubin serum akan cepat menjadi normal dan mekonium lebih cepat keluar sehingga menurunkan risiko kejadian hiperbilirubinemia pada bayi baru lahir.

Penerapan IMD akan meningkatkan keberhasilan bayi baru lahir untuk menyusu kemudian. Keberhasilan IMD yang dilanjutkan dengan keteraturan menyusu bayi akan lebih awal mendapatkan kolostrum. Kolustrum adalah air susu ibu yang keluar pertama kali, dan merupakan laksatif alami yang berfungsi sebagai pencahar. Kolustrum akan merangsang percepatan pengeluaran mekonium, didalam mekonium atau feses yang pertama kali dikeluarkan bayi mengandung zat-zat sisa dan bilirubin sehingga dengan IMD akan menurunkan kejadian hiperbilirubinemia fisiologis.

Produksi ASI ibu juga tidak kalah penting untuk diperhatikan, karena keberhasilan laktasi bukan hanya dari faktor bayi. Manajemen stres yang baik oleh ibu post partum merupakan salah satu faktor penting. Dukungan keluarga sangat dibutuhkan oleh ibu post partum. Menurut studi yang dilaksanakan oleh Yanto (2017) menjelaskan bahwa dukungan keluarga yang tepat dapat meningkatkan kualitas pelayanan dan pelaksanaan terapi pasien.

Pengaruh inisiasi menyusu dini yang baik terhadap penurunan kadar billirubin serum total mengindikasikan bahwa pentingnya kegiatan tersebut, serta peran perawat sebagai pemberi pelayanan juga harus ditingkatkan dalam menunjang pelaksanaan inisiasi menyusu dini ibu post partum. Peningkatan kompetensi perawat sejak perawat baru juga merupakan hal yang penting sehingga mampu memberikan pelayanan keperawatan yang optimal (Yanto\&Rejeki, 2017). Kompetensi perawat maternitas juga dapat ditingkatkan dengan melakukan metode pembelajaran yang baik antara staf keperawatan. Sehingga kualitas pelayanan keperawatan dapat terjaga dengan baik (Wuryanto, 2017). 


\section{REFERENSI}

American Academy of Pediatrics Subcommittee on Hyperbilirubinemia. (2004). Management of Hyperbilirubinemia in the Newborn Infant 35 or more weeks of gestation. Pediatrics, 114(1), 297.

Dewi,V.N.L. (2014). Asuhan Neonatus Bayi dan Anak Balita.Jakarta : Salemba Medika.

Direktorat Jenderal Bina Pelayanan Medik. (2010). Tatalaksana Bayi Baru Lahir di Rumah Sakit. Buku panduan. Kementrian Kesehatan RI.

Fikawati, S. \& Syafiq, A. (2010). Kajian Implementasi dan Kebijakan Air Susu Ibu Eksklusif dan Inisiasi Menyusu Dini di Indonesia. Makara kesehatan, 14(1), 17-24.

Irianti, A. (2015). Hubungan antara Berat Badan Lahir, Jenis Persalinan, dan Hipoglikemia dengan kejadian Hiperbilirubinemia Patologis pada Neonatus di RSUD Tugurejo Semarang. (Skripsi tidak dipublikasikan).

Juffrie, M., Soenarto, S.S.Y., Oswati, H., Arief, S., Rosalina, I., \& Mulyani, N.S., (2012). Buku Ajar Gastroenterologi-Hepatologi. Jilid 1. Jakarta : Balai Pustaka.

Kosim, M.S., Yunanto, A., Dewi, R., Sarosa, G.I., \& Usman, A. (2008). Buku Ajar Neonatologi. Edisi I. Jakarta : IDAI.

Lubis, B.M., Rasyidah, R., Syofiani, B., Sianturi, P., Azlin, E., \& Tjipta, G.D. (2016). Rasio Bilirubin Albumin pada Neonatus dengan Hiperbilirubinemia. Sari Pediatri, 15(5), 292297.

Mauliku, N.E., \&Nurjanah, A. (2010). Faktor-faktor pada Ibu Bersalin yang berhubungan dengan Kejadian Hiperbillirubin pada Bayi Baru Lahir di Rumah Sakit Dustira Cimahi tahun 2009.Jurnal Kesehatan Kartika. Dikutip tanggal 5 Juli 2017.

Pudjiadi, A.H., Handryastuti, S., Idris, N.S., Gandaputra, E.P., \& Harmoniati, E.D. (2011).
Pedoman Pelayanan Medis Ikatan Dokter Anak Indonesia Edisi II. Jakarta: Badan Penerbit Ikatan Dokter Anak Indonesia, 98104.

Rusli, H.U. (2008). Inisiasi Menyusui Dini plus ASI Eksklusif. Puspa swara.

Sareharto, T.P., \&Wijayahadi, N. (2016). Kadar Vitamin E Rendah sebagai Faktor Risiko Peningkatan Bilirubin Serum pada Neonatus. Sari Pediatri, 11(5), 355-362.

Saputra, N.P.K., \& Lasmini, P.S. (2016). Pengaruh Inisiasi Menyusu Dini terhadap Waktu Pengeluaran dan Perubahan Warna Mekonium serta Kejadian Ikterik Fisiologi.JIK (Jurnal Ilmu Kedokteran), 9(2), 87-94. Diakses pada tanggal 12 Juli 2017.

Suryandari, A.E. \& Agustina, E.E. (2013). Perbedaan waktu pemberian kolustrumterhadap kejadian ikterus fisiologis pada bayi baru lahir di RSU. PROF. DR.Margono Soekarjo tahun 2013.Jurnal Ilmu Kebidanan (Journal of Midwifery Science). Diakses pada tanggal 5 Juli 2017.

Wuryanto, E., Rahayu, G., Emilia, O., , H., dan Octavia, A. (2017). Application of an outcome present test-peer learning model to improve clinical reasoning of nursing students in the intensive care unit. Annals of Tropical Medicine and Public Health, 10(3), 657-663. doi: 10.4103/atmph.atmph_201_17.

Yanto, A., dan Rejeki, S. (2017). The Related Factors To Decreased The New Graduate Nurses Work Stress Level Of In Semarang. Nurscope: Jurnal Penelitian dan Pemikiran Ilmiah Keperawatan, 3(2), 1-10.

Yanto, A., dan Setyawati, D. (2017). Dukungan Keluarga Pada Pasien Diabetes Mellitus Tipe 2 Di Kota Semarang. Paper presented at the Seminar Nasional Universitas Muhammadiyah Semarang, Universitas Muhammadiyah Semarang. 